\title{
Performance of Varieties and Nutrient Levels on Growth and Yield of Linseed (Linum usitatissimum L.)
}

\author{
Vibha Sahu*, R. B. Tiwari and S. N. Khajanji \\ ${ }^{1}$ Department of Agronomy, College of Agriculture, Indira Gandhi Krishi Vishwavidyalaya, \\ Raipur- 492012 (Chhattisgarh), India \\ ${ }^{2}$ Barrister Thakur Chhedilal, College of Agriculture and research Station, Bilaspur-495001 \\ (Chhattisgarh), India \\ *Corresponding author
}

\section{A B S T R A C T}

\begin{tabular}{|l|}
\hline K e y w o r d s \\
Economics, \\
Linseed, Nutrient \\
levels, Variety, \\
Yield attributes, \\
Yield
\end{tabular}

A field experiment was conducted to study the"Performance of varieties and nutrient levels on growth and yield of linseed (Linum usitatissimum L.)" at the Research Farm of Barrister Thakur Chhedilal, College of Agriculture and research Station, Bilaspur (Chhattisgarh) during 2019-20. The result revealed that growth and yield parameter like plant height $(70.84 \mathrm{~cm})$, primary $(4.11)$, \& secondary branches per plant $(22.86)$, dry matter accumulation (7.44), number of capsule plant ${ }^{-1}(60.78)$, number. of seed capsule ${ }^{-1}$ (8.33), test weight $(7.34 \mathrm{~g})$, seed yield $(1483.70 \mathrm{~kg} / \mathrm{ha})$, straw yield $(3290.58 \mathrm{~kg} / \mathrm{ha})$, harvest index $(31.07 \%)$, \& benefit cost ratio (2.41) were significantly higher with variety $\mathrm{V}_{1}$ (RLC-92) as compared to the other variety but was at par with $\mathrm{V}_{5}$ (RLC-148). Similarly, in nutrient levels, the treatment $\mathrm{F}_{3}(150 \% \mathrm{RDF})$ obtained significantly higher growth and yield parameter like plant height $(62.17 \mathrm{~cm})$, primary $(4.09)$, \& secondary branches per plant (21.96), dry matter accumulation (7.81), number of capsule plant ${ }^{-1}$ (60.24), number of seed capsule ${ }^{-1}(8.39)$, test weight $(7.44 \mathrm{~g})$, seed yield (1409.25 kg /ha), straw yield (3223.11 kg / ha), harvest index (30.40), as compared to $\mathrm{F}_{1}(50 \% \mathrm{RDF})$ but was at par with $100 \%$ RDF (F2) except B:C ratio. Highest B:C ratio obtained by $\mathrm{F}_{2}(2.13)$ However, since difference in yield and yield attributes between $F_{3}$ and $F_{2}$ was nonsignificant. Hence nutrient levels $\mathrm{F}_{2}(100 \% \mathrm{RDF})$ is economically viable for linseed crop.

\section{Introduction}

India is one of the world's leading oilseed growing country and oilseed sector has an important position in the agricultural industry. India is the world's fifth largest vegetable oil economy, alongside United States, China,
Brazil and Argentina. India accounts for 12$15 \%$ of the global oilseeds area, 7-8\% of oilseeds production, 6-7\% of vegetable oils production, $9-12 \%$ of vegetable oils imported and $9-10 \%$ of the edible oils consumed. The total production of oilseed in the country is estimated at 31.42 million tonnes in 2018-19. 
Oilseeds production during 2018-19 is 1.77 million tonnes higher than the average Fiveyear production of oilseeds. (anonymous 2018-19).

India ranks 5th among world's linseed producing countries. In India linseed grown an area of 3.31 lakh ha. with 1.72 lakh tonnes production and its productivity is $523 \mathrm{~kg} / \mathrm{ha}$. [anonymous 2017-18]. In Chhattisgarh state linseed cultivated in an area of 0.45 lakh ha.with 0.14 lakh tonnes production and its productivity is $301 \mathrm{~kg} / \mathrm{ha}$ [anonymous 2017 18]. Linseed consists of around $40 \%$ fat, $28 \%$ dietary fibre, $21 \%$ protein, $6 \%$ carbohydrates and 4\% ash (Vaisey-Genser and Morris, 2010). Linseed plant is an abundant source of both edible and nonedible oil. Industrial oil is an important ingredient for paint, varnish, and stain manufacturing (Matheson, 1976). Edible linseed oil is used for human consumption and contains alpha-linolenic acid (ALA), a polyunsaturated fatty acid that provides nutritional and health benefits (Wood, 1997; Flax Council of Canada, 2004).

The productivity of linseed in Chhattisgarh state is below the national productivity. There are many factors responsible for low productivity of linseed in this state but selection of improved variety suitable for the environment and proper fertilization have prominent factors responsible for low productivity of linseed. Varieties differ in their yield ability depending on various physiological processes regulated by both genetic makeup and environment. It is the fact that, under all environmental conditions, a specified genotype does not exhibit the same phenotypic characteristics and different genotypes respond differentially to a specified environment and usually differ in their relative ranking (Ebehort and Russel, 1966). Plant nutrition is also a key input to improve productivity. Among the agro-techniques that can increase their productivity is judicious application of nutrients, especially nitrogen, phosphorus and potash (Pali and Tripathi 2000). Under the conditions explained above to generate more information. The present study is carried out on Performance of varieties and nutrient levels on growth and yield of linseed (Linum usitatissimum L.) with the following objectives include to find out the suitable variety of linseed for higher productivity and profitability. To find out the optimum nutrient level for variety of linseed. And also to compute the economics of different treatments under investigation.

\section{Materials and Methods}

\section{Study area}

The field experiment was conducted during Rabi season of 2019-20 at the Research Farm of Barrister Thakur Chhedilal, College of Agriculture and research Station, Bilaspur (Chhattisgarh). The Research Farm is situated at $22.09^{\circ} \mathrm{N}$ latitude, $82.12^{\circ} \mathrm{E}$ longitude and at an altitude of $292 \mathrm{~m}$ above mean sea level. The region falls under the Eastern plateau and hill region (Agro-climatic zone-VII) of India. The state of Chhattisgarh is classified into 3 agro-climatic zones, of which Bilaspur falls under the state zone of Chhattisgarh plains. The soil of the experimental site was sandy loam in texture, neutral in reaction $(\mathrm{pH} 7.09)$, low in organic matter $(0.60 \%)$ and low in nitrogen $\left(237.5 \mathrm{~kg} \mathrm{ha}{ }^{-1}\right)$, medium in phosphorus $\left(14.34 \mathrm{~kg} \mathrm{ha}{ }^{-1}\right)$ \&high in potassium (361.09 $\mathrm{kg} \mathrm{ha}^{-1}$ ) contents. During the experimental period, climatic parameters were favorable for better growth and development of linseed.

\section{Treatments detail}

The experiment has been carried out in factorial randomized block design (FRBD) with three replications and fifteen treatment combinations. The treatment consisting of 5 
varieties viz., ( $\left.\mathrm{V}_{1}\right)$ RLC-92, ( $\left.\mathrm{V}_{2}\right)$ RLC-133, $\left(\mathrm{V}_{3}\right)$ RLC-138, $\left(\mathrm{V}_{4}\right)$ RLC-143, and $\left(\mathrm{V}_{5}\right)$ RLC148 and 3 nutrient levels i.e., $\mathrm{F}_{1}$ [50 \% RDF], $\mathrm{F}_{2}[100 \% \mathrm{RDF}]$, and $\mathrm{F}_{3}[150 \% \mathrm{RDF}]$.

\section{Crop management}

The crop was sowing on $9^{\text {th }}$ November 2019 and were harvested at maturity of the varieties (RLC-133 on $2^{\text {nd }}$ march 2020, RLC-92, RLC138 and RLC-148 on $7^{\text {th }}$ march 2020 , and RLC-143 on $11^{\text {th }}$ march 2020). All the recommended agronomic management practices were followed except for the treatments.

\section{Statistical analysis}

Standard procedure was adopted for recording the data on various growth and yield parameters. Data collected were statistically analyses by the procedure suggested by Gomez and Gomez (1984).

\section{Results and Discussion}

Growth, yield attributing characters and yield of linseed

The seed yield, ultimate result of various interacting growth, development and yield contributing character. The data shown in table 1 and table 2 revealed that growth, yield attributing character and yield were significantly affected due to varieties and nutrient levels. Variety $\mathrm{V}_{1}$ (RLC-92) gave significantly plant height $(70.84 \mathrm{~cm})$, primary branches plant ${ }^{-1}$ (4.11), secondary branches plant ${ }^{1}$ (22.86), dry matter accumulation (7.44), number of capsule plant ${ }^{-1}$ (60.78), number of seed capsule ${ }^{-1}(8.33)$, test weight $(7.34 \mathrm{~g})$, seed yield $(1483.70 \mathrm{~kg} / \mathrm{ha})$, straw yield (3290.58 kg / ha), and HI (31.07\%), were significantly higher with variety $\mathrm{V}_{1}$ (RLC-92) as compared to the other variety. However, capsules per plant, seeds per capsules, test weight $(\mathrm{g})$, seed yield $(\mathrm{kg} / \mathrm{ha})$, straw yield (kg/ha) and harvest index (\%) was at par with $\mathrm{V}_{5}$ (RLC-148).

The lowest no. of primary branches per plant (3.49) and secondary branches per plant (19.76), dry matter accumulation (6.63g), number of capsules per plant (47.74), number of seed per capsules (7.67), seed yield $\left(1151.86 \mathrm{~kg} \mathrm{ha}^{-1}\right)$, straw yield $\left(2921.37 \mathrm{~kg} \mathrm{ha}^{-}\right.$ $\left.{ }^{1}\right)$, \& harvest index (28.31) was recorded with $\mathrm{V}_{3}$ (RLC-138).

The lowest plant height $(49.23 \mathrm{~cm})$ and test weight $(6.90 \mathrm{~g})$. was recorded with the variety $\mathrm{V}_{4}$ (RLC-143). The difference in variety $\mathrm{V}_{1} \&$ $\mathrm{V}_{5}$ was not significant hence both varieties are suitable for this region. The increase in yield might be due to difference in growth and yield attributing characters of the varieties i.e. plant height, no. of branches, no. of capsules plant $^{-1}$, no. of grain capsules ${ }^{-1}$, and test weight resulted in enhancement of overall grain production $\mathrm{kg} \mathrm{ha}^{-1}$ of the linseed crop. The results were corroborated with the finding of Lodhi and Chauhan et al., (2002), Gokhale et al., (2008), Prakash et al., (2015), and Kurrey et al., (2019).

Similarly, in nutrient levels, application of $150 \%$ RDF $\left(\mathrm{F}_{3}\right)$ recorded a higher value of growth parameters viz., plant height (62.17 $\mathrm{cm}$ ), number of primary branches plant $^{-1}$ (4.09), secondary branches plant ${ }^{-1}$ (21.96), and dry matter accumulation (7.81g), which was significantly superior over $50 \%$ RDF $\left(\mathrm{F}_{1}\right)$ and $100 \% \operatorname{RDF}\left(\mathrm{F}_{2}\right)$. The Lowest plant height $(56.24 \mathrm{~cm})$, no. of primary branches plant $^{-1}(3.35)$, no. of secondary branches plant ${ }^{-1}$ (20.07) and dry matter accumulation $(6.16$ g) was recorded with the application of $50 \%$ $\operatorname{RDF}\left(\mathrm{F}_{1}\right)$. The yield and yield attributing characteristics viz., capsules per plant (60.24), seed per capsules (8.39). test weight (7.44 g), seed yield $\left(1409.25 \mathrm{~kg} \mathrm{ha}^{-1}\right)$, straw yield $\left(3223.11 \mathrm{~kg} \mathrm{ha}^{-1}\right)$, and harvest index (30.41 $\%$ ), were significantly higher in the treatment $\mathrm{F}_{3}(150 \% \mathrm{RDF})$ over treatment $\mathrm{F}_{1}(50 \%$ 
RDF) but was statistically equal to treatment $\mathrm{F}_{2}$ (100\% RDF).The lowest capsules per plant (46.96), seed per capsules (7.47). test weight $(6.84 \mathrm{~g})$, seed yield $\left(1139.92 \mathrm{~kg} \mathrm{ha}^{-1}\right)$, straw yield $\left(2937.07 \mathrm{~kg} \mathrm{ha}^{-1}\right)$, and harvest index $(27.91 \%)$ was recorded with the application of $50 \% \operatorname{RDF}\left(\mathrm{F}_{1}\right)$. However, since difference in yield and yield attributes between $F_{3}$ and $F_{2}$ was non-significant. This might be due to increase in yield attributing characters with the application of $150 \%$ RDF. Similar results were also noted by Kumar et al., (2016) and Devedee et al., (2019).

\section{Economics of linseed}

Among all the five linseed varieties cost of cultivation were similar (Rs $19129.19 \mathrm{ha}^{-1}$ ). The variety $\mathrm{V}_{1}$ (RLC-92) recorded higher Gross return (Rs 65283.85 ha ${ }^{-1}$ ), net return (Rs46154.65 ha ${ }^{-1}$ ) and B: C ratio (2.41) were significantly superior over other varieties but was at par with $\mathrm{V}_{5}$ (RLC-148). This increase in gross return, net return and $\mathrm{B}: \mathrm{C}$ is due to higher grain yield received with $\mathrm{V}_{1}$ and $\mathrm{V}_{5}$. The results were corroborated with the finding of Maurya et al., (2017). Lowest gross return (Rs $50682.64 \mathrm{ha}^{-1}$ ), net return (Rs31553.45 ha ${ }^{-1}$ ) and B: C ratio (1.65) was obtained with $\mathrm{V}_{3}$ (RLC-138). Similarly, cost of cultivation were minimum (Rs17598.19 ha $\left.{ }^{1}\right)$ with the application of $50 \% \operatorname{RDF}\left(\mathrm{F}_{1}\right)$ which has increased by increase in nutrient levels.

Table.1 Effect of varieties and nutrient levels on growth attributes of linseed at harvest

\begin{tabular}{|c|c|c|c|c|}
\hline \multirow[t]{2}{*}{ Treatment } & \multicolumn{4}{|c|}{ Plant height $(\mathbf{c m})$} \\
\hline & $\begin{array}{l}\text { Plant height } \\
\text { (cm) }\end{array}$ & $\begin{array}{c}\text { Primary } \\
\text { branches }^{-1} \\
\text { plant }^{-1}\end{array}$ & $\begin{array}{c}\text { Secondary } \\
\text { branches }^{-1} \\
\text { plant }^{-1}\end{array}$ & $\begin{array}{l}\text { Dry matter } \\
\text { accumulation } \\
\text { (g) }\end{array}$ \\
\hline \multicolumn{5}{|l|}{ A. Varieties } \\
\hline V1-RLC-92 & 70.84 & 4.11 & 22.86 & 7.44 \\
\hline V2-RLC-133 & 59.02 & 3.62 & 20.71 & 6.89 \\
\hline V3-RLC-138 & 50.42 & 3.49 & 19.76 & 6.63 \\
\hline V4-RLC-143 & 49.23 & 3.58 & 20.04 & 6.81 \\
\hline V5-RLC-148 & 64.34 & 3.80 & 21.89 & 7.00 \\
\hline S. Em \pm & 1.21 & 0.07 & 0.52 & 0.16 \\
\hline CD at $5 \%$ & 3.49 & 0.21 & 1.51 & 0.45 \\
\hline \multicolumn{5}{|c|}{ B. Nutrient levels } \\
\hline N1-50\% RDF & 56.24 & 3.35 & 20.07 & 6.16 \\
\hline N2-100\% RDF & 57.90 & 3.72 & 21.13 & 6.89 \\
\hline N3-150\% RDF & 62.17 & 4.09 & 21.96 & 7.81 \\
\hline S. Em \pm & 0.93 & 0.06 & 0.40 & 0.12 \\
\hline CD at $5 \%$ & 2.71 & 0.16 & 1.17 & 0.35 \\
\hline \multicolumn{5}{|c|}{ C. Interaction } \\
\hline S. Em \pm & 2.09 & 0.12 & 0.90 & 0.27 \\
\hline CD at $5 \%$ & NS & NS & NS & NS \\
\hline
\end{tabular}


Table.2 Yield attributing characters and yield of linseed as influenced by varieties and nutrient levels

\begin{tabular}{|c|c|c|c|c|c|c|c|}
\hline \multirow[t]{2}{*}{ Treatment } & \multicolumn{7}{|c|}{ Yield attributing characters } \\
\hline & $\begin{array}{l}\text { Capsules } \\
\text { /plant }\end{array}$ & $\begin{array}{l}\text { Seeds / } \\
\text { capsule }\end{array}$ & $\begin{array}{c}\text { Test } \\
\text { weight } \\
\text { (g) }\end{array}$ & $\begin{array}{c}\text { Seed yield } \\
\text { (kg/ha) }\end{array}$ & $\begin{array}{l}\text { Stover } \\
\text { yield } \\
\left(\mathrm{kg} \mathrm{ha}^{-1}\right)\end{array}$ & $\begin{array}{c}\text { Harvest } \\
\text { index } \\
(\%)\end{array}$ & $\begin{array}{l}\text { B:C } \\
\text { Ratio }\end{array}$ \\
\hline \multicolumn{8}{|c|}{ A. Varieties } \\
\hline V1-RLC-92 & 60.78 & 8.33 & 7.34 & 1483.70 & 3290.58 & 31.07 & 2.41 \\
\hline V2-RLC-133 & 53.63 & 7.95 & 7.08 & 1281.95 & 3062.33 & 29.47 & 1.94 \\
\hline V3-RLC-138 & 47.74 & 7.67 & 7.27 & 1151.86 & 2921.37 & 28.31 & 1.65 \\
\hline V4-RLC-143 & 52.15 & 7.82 & 6.90 & 1176.42 & 2949.69 & 28.38 & 1.70 \\
\hline V5-RLC-148 & 55.86 & 8.18 & 7.25 & 1426.40 & 3222.48 & 30.66 & 2.28 \\
\hline S. Em \pm & 2.38 & 0.13 & 0.11 & 26.16 & 73.03 & 0.48 & 0.06 \\
\hline CD at $5 \%$ & 6.88 & 0.37 & 0.30 & 75.78 & 211.52 & 1.39 & 0.18 \\
\hline \multicolumn{8}{|c|}{ B. Nutrient levels } \\
\hline N1-50\% RDF & 46.96 & 7.47 & 6.84 & 1139.92 & 2937.07 & 27.91 & 1.85 \\
\hline $\begin{array}{l}\text { N2-100\% } \\
\text { RDF }\end{array}$ & 54.89 & 8.12 & 7.22 & 1363.03 & 3107.70 & 30.40 & 2.13 \\
\hline $\begin{array}{l}\text { N3-150\% } \\
\text { RDF }\end{array}$ & 60.24 & 8.39 & 7.44 & 1409.25 & 3223.11 & 30.41 & 2.01 \\
\hline S. Em \pm & 1.84 & 0.10 & 0.08 & 20.27 & 56.57 & 0.37 & 0.05 \\
\hline CD at $5 \%$ & 5.33 & 0.28 & 0.24 & 58.70 & 163.85 & 1.07 & 0.14 \\
\hline \multicolumn{8}{|c|}{ C. Interactions } \\
\hline S. Em \pm & 4.11 & 0.22 & 0.18 & 45.32 & 126.50 & 0.83 & 0.11 \\
\hline CD at $5 \%$ & NS & NS & NS & NS & NS & NS & NS \\
\hline
\end{tabular}

Treatment $\mathrm{F}_{3} \quad(150 \% \quad \mathrm{RDF})$ recorded a significantly higher cost of cultivation (Rs20660.20 ha-1), Gross return (Rs 62008.03 $\mathrm{ha}^{-1}$ ), and net return (Rs $41347.83 \mathrm{ha}^{-1}$ ) as compared to treatment $\mathrm{F}_{1}(50 \% \mathrm{RDF})$ but was statistically equal to treatment $\mathrm{F}_{2}(100 \%$ RDF) expect benefit cost ratio. Treatment $F_{2}$ gave high benefit- cost ratio (2.13). The lowest gross return (Rs $50157.48 \mathrm{ha}^{-1}$ ), net return (Rs $\left.32559.29 \mathrm{ha}^{-1}\right)$ and benefit cost ratio $(1.85)$ was recorded treatment $\mathrm{F}_{1}(50 \% \mathrm{RDF})$.

In conclusion on the basis of the field experiment conducted during rabi season of 2019-20, it could be concluded that, the linseed variety $\mathrm{V}_{1}$ (RLC-92) showed superiority in all growth and yield attributing characters but was at par with $\mathrm{V}_{5}$ (RLC-148).
The difference in variety $\mathrm{V}_{1} \& \quad \mathrm{~V}_{5}$ was not significant hence both varieties are suitable for this region. Similarly, in nutrient levels, the treatment $\mathrm{F}_{3}$ obtained significantly superior over $F_{1}$ but was at par with treatment $\mathrm{F}_{2}$ however since difference in yield and yield attributes between $\mathrm{F}_{3}$ and $\mathrm{F}_{2}$ was nonsignificant. Hence nutrient levels $\mathrm{F}_{2}(100 \%)$ is economically viable for linseed crop.

\section{References}

Anonymous (2017-18)- Agricultural Statistics Division, Directorate of Economics \& Statistics, Department of Agriculture, Cooperation and Farmers Welfare, Third Advance Estimates of Production of Commercial Crops for 2017-18. 
Anonymous (2017-18)-Directorate of Economics and Statistics. Ministry of Agricultural (Govt. of India). New Delhi. Pp.: 39-40 and 43-44.

Anonymous (2018-19)- Agricultural Statistics Division, Directorate of Economics \& Statistics, Department of Agriculture, Cooperation and Farmers Welfare, Third Advance Estimates of Production of Foodgrains for 2018-19

Devedee. A.K., Singh, R.K., Meena, R.N. and Choudhary, Kartikeya. (2019) Effect of moisture conservation on growth and yield of linseed under varying fertility levels, Journal of Crop and Weed, 15(1): 198-200.

Ebehort, S.A. and Russell, W.A., (1966). Stability parameters for comparing varieties, Crop Science, 60, 36-40.

Flax Council of Canada (2004). Flax and the low carbohydrate diet. Flax Focus 17:2, $1-8$.

Gomez, K. A. and Gomez, A.A. (1984). Statistical procedure for Agriculture Research. A Willey- Inter-Science Publication, John Willey and Sons, New York. Pp.108-127

Gokhale, D.N., Wadhvane, S.V., Kalegore, N.K., Khalge, M.L. and Shaikh, F.G (2008). Response of linseed (Linum usitatissimum L.) Varieties to row spacing and phosphorus level under irrigated condition. J. Oilseeds Res., 25 (1): (9495).

Kumar, Santosh., Singh, J.K. and Vishwakarma, Akhilesh (2016). Effect of NPK levels and biofertilizers on quality parameters and seed yield of linseed (Linum usitatissimum L) verities under irrigated condition. International Quarterly Journal of Life Science, 11(2),1339-1343.

Kurrey D and Singh R.K. (2019) Growth and yield analysis of hydrogel and Trichoderma combination in linseed under rainfed condition. Bull. Env. Pharmacol.LifeSci, Vol 8 (12) 33-37.

Lodhi Matadin and Chauhan D.V.S. (2002). Studies on the effect of fertilizer dates of sowing varieties and number of irrigation on yield attributes yield and quality of linseed under Bundelkhand conditions of U.P. Ph.D. Thesis of Agronomy (2002). Bundelkhand university, Jhansi.

Matheson, E. M. (1976). Linseed. In: Vegetable Oil Seed Crops in Australia. Holt.

Maurya, A.C., Raghuveer, M., Goswami, G. and Kumar, S. 2017. Influences of date of sowing on yield attributes and yield of linseed (Linum usitatissimumL.) varieties under dryland condition. Int. J. Curr. Microbiol. App. Sci6 (7): (481-487).

Pali, G.P. and Tripathi, R.S., (2000). Performance of linseed (Linum usitatissimumL.) varieties under varying sowing and fertilizer management under rainfed condition, Indian Journal of Agronomy, 45(4), 771-775.

Prakash G., Singh R.K., Singh A., Singh K. 2015. Growth, yield, nutrient uptake and quality of linseed (Linum usitatissimumL.) varieties as affected by varying sowing dates. J. Environ..Eco. Vol 33: (271-274).

Vaisey-Genser M, Morris DH (2010). Flaxseed: Health Nutrition and Functionality. Flax Council of Canada, Winnipeg, Manitoba.

Wood, I. M. (1997). Fibre Crops - New opportunities for Australian agriculture.

\section{How to cite this article:}

Vibha Sahu, R. B. Tiwari and Khajanji, S. N. 2020. Performance of Varieties and Nutrient Levels on Growth and Yield of Linseed (Linum usitatissimum L.). Int.J.Curr.Microbiol.App.Sci. 9(07): 2825-2830. doi: https://doi.org/10.20546/ijcmas.2020.907.334 